\title{
Short communication Underarm antiperspirants/deodorants and breast cancer
} Philippa D Darbre

\author{
School of Biological Sciences, Biomedical Sciences, Hopkin's Building, University of Reading, Reading RG6 6UB, UK
}

Corresponding author: Philippa D Darbre, p.d.darbre@reading.ac.uk

Published: 13 December 2009

This article is online at

http://breast-cancer-research.com/supplements/11/S3/S?

\section{Introduction}

Clinical studies dating back decades report a disproportionately high number of female breast cancers originating in the upper outer quadrant of the breast [1], and although this is attributed to a greater amount of epithelial tissue in that region, it is also the area to which underarm cosmetic products are applied [2,3]. Early studies reported $31 \%$ of cancers in the upper outer quadrant [1], but later studies in the 1990 s report up to $61 \%[2,3]$. The annually recorded quadrant incidence of breast cancer in Britain documents a rise in England and Wales from 47.9\% in the upper outer quadrant in 1979 to $53.3 \%$ in 2000 , and in Scotland a rise from $38.3 \%$ in the upper outer quadrant in 1980 to $54.7 \%$ in 2001 [4]. Any increase in the disproportionality of breast cancer in the upper outer quadrant would be inconsistent with an explanation relating to the greater amount of target epithelial tissue in that region but does parallel the increasing use of cosmetics in the underarm area [2-5].

\section{How could a link exist mechanistically between underarm cosmetics and breast cancer?}

An extensive number of cosmetic products are applied topically on and around the human breast on a daily basis, often multiple times a day, including not only underarm antiperspirant/deodorant products but also body lotions, body sprays, moisturising creams, breast firming/enhancing creams and suncare products. These products are not rinsed off but left on the skin, allowing for continuous dermal exposure, absorption and deposition into underlying tissues, which may be further increased by abrasions in the skin created by shaving [2,3,5-7]. The extent to which chemicals absorbed by this route escape metabolism remains unknown, but they would certainly escape the systemic metabolism to which orally derived chemicals would be subjected [5-7].

With current cultural pressures, these products are used with increasing frequency and quantity $[8,9]$, and by ever younger children including babies [3], and the effects of long-term low-dose exposure to these mixtures of multiple chemicals are unknown. The diversity in usage of these cosmetics and the range of different products available provides ample
Breast Cancer Research 2009, 11(Suppl 3):S5

(doi:10.1186/bcr2424)

(c) 2009 BioMed Central Ltd

possibility for cancer to arise through issues of quantity used, through pattern of usage or through individual susceptibility to specific product formulations $[2,3,5-7]$.

Underarm cosmetics contain a variety of chemicals added for different functional reasons (see Table 1), many of which individually already have a known toxicity profile [5-7]. If any of these chemicals play a role in breast cancer development, however, then the challenge is to identify the specific chemical culprits and their mode of action in breast epithelial cells.

Any carcinogenic action by the constituent chemicals may involve an ability to interact with DNA, resulting in genotoxic activity or an ability to interfere with oestrogen action $[2,3,5]$. The role of oestrogen in the development and progression of breast cancer is well established [10] but the ability of a cocktail of environmental oestrogen-mimicking chemicals to also drive the development and growth of breast cancers is worthy of serious consideration, especially in relation to those chemicals known to be detectable as present in the human breast [5]. Some studies have investigated whether environmental oestrogens entering the human breast through diet (for example, organochlorine pesticides, polychlorinated biphenyls in animal fat, phytoestrogens or herbicides through fruit and vegetables) or through the domestic environment (for example, bisphenol A/phthalates in plastics, alkyl phenols in detergents, polybrominated diphenylethers in soft furnishings) may be linked to the development of breast cancer, and topical application of cosmetic chemicals with oestrogenic properties provides another exposure route [5].

Only two epidemiological studies have attempted to address directly the issue of underarm cosmetic use and breast cancer. Mirick and colleagues reported there to be no difference in current use of antiperspirant/deodorant products between breast cancer patients and nonaffected matched controls [11]. By contrast, McGrath reported within a population of breast cancer patients that those who used more antiperspirant products were diagnosed with breast cancer at an earlier age [9]. The first study is limited by the reliance on self-reported information, by the lack of a nonuser 
Table 1

Components of cosmetics applied to the underarm and breast area

\begin{tabular}{|c|c|c|c|}
\hline Component & Mechanism of action & Examples of compounds used & $\begin{array}{l}\text { Compounds with known } \\
\text { oestrogenic activity }\end{array}$ \\
\hline Antiperspirant & $\begin{array}{l}\text { Mediates formation of a physical plug at } \\
\text { the top of the sweat duct to prevent sweat } \\
\text { escaping onto the skin surface }\end{array}$ & $\begin{array}{l}\text { Mainly aluminium salts, often as aluminium } \\
\text { chlorhydrate }\end{array}$ & $\begin{array}{l}\text { Aluminium is a } \\
\text { metalloestrogen }\end{array}$ \\
\hline Deodorant & $\begin{array}{l}\text { To mask, modify or prevent body odour. } \\
\text { Since undesirable smell is generated } \\
\text { through the action of bacteria on the sweat } \\
\text { on the skin surface, antimicrobial agents } \\
\text { act to kill bacteria }\end{array}$ & $\begin{array}{l}\text { Phenolic compounds, often chlorinated } \\
\text { such as triclosan }\end{array}$ & Triclosan \\
\hline Preservative & $\begin{array}{l}\text { To prevent growth of microorganisms } \\
\text { during product storage }\end{array}$ & $\begin{array}{l}\text { Alkyl esters of } p \text {-hydroxybenzoic acid } \\
\text { (parabens) }\end{array}$ & $\begin{array}{l}\text { Methylparaben, ethylparaben, } \\
n \text {-propylparaben, } \\
n \text {-butylparaben, } \\
\text { isobutylparaben, } \\
\text { benzylparaben }\end{array}$ \\
\hline $\begin{array}{l}\text { Fragrance/ } \\
\text { fragrance fixer }\end{array}$ & $\begin{array}{l}\text { To give a good scent to the consumer } \\
\text { product }\end{array}$ & $\begin{array}{l}\text { Synthetic musks, including nitromusks } \\
\text { and polycyclic musks. Benzyl salicylate, } \\
\text { benzyl benzoate, butylphenymethyl- } \\
\text { propional (Lilial) }\end{array}$ & $\begin{array}{l}\text { Polycyclic musks HHCB, } \\
\text { AHTN. Nitromusks musk } \\
\text { xylene, musk ketone. Benzyl } \\
\text { salicylate, benzyl benzoate, } \\
\text { butylphenylmethylpropional }\end{array}$ \\
\hline $\begin{array}{l}\text { Spreading/ } \\
\text { conditioning }\end{array}$ & $\begin{array}{l}\text { To ensure even distribution of } \\
\text { components across the skin surface }\end{array}$ & $\begin{array}{l}\text { Linear (dimethicone) and cyclic } \\
\text { (cyclomethicone) siloxanes }\end{array}$ & Octamethylcyclotetrasiloxane \\
\hline Plasticiser & Solvent, moisturiser, fragrance carrier & Phthalates & $\begin{array}{l}\text { Dibutylphthalate, } \\
\text { di(2-ethylhexyl)phthalate, } \\
\text { diethylphthalate, } \\
\text { butylbenzylphthalate }\end{array}$ \\
\hline Surfactant & For cleansing purposes & Alkyl phenols & Nonylphenol \\
\hline UV filter & $\begin{array}{l}\text { Chemicals act to absorb UVA and UVB } \\
\text { light. Also added to aid product stability }\end{array}$ & $\begin{array}{l}\text { Organic compounds, often } \\
\text { benzophenone derivatives }\end{array}$ & $\begin{array}{l}\text { Benzophenone-3, } \\
\text { benzophenone-2, } \\
\text { octyl-methoxycinnamate, } \\
\text { 3-(4-methylbenzylidene)- } \\
\text { camphor, homosalate, octyl- } \\
\text { dimethyl-p-aminobenzoic acid }\end{array}$ \\
\hline
\end{tabular}

For references refer to published reviews [5-7]. HHCB, 1,3,4,6,7,8-hexahydro-4,6,6,7,8,8,-hexamethylcyclopenta- $\gamma$-2-benzopyran; AHTN, 6-acetyl1,1,2,4,4,7-hexamethylteralin.

population and by the lack of consideration to historical usage. The second study suggests a dose-response relationship to chemical exposure and sensitivity at a younger age, consistent with patterns of breast cancer development [5], but does not exclude other risk factors or the issue that cosmetic use is simply higher in younger women.

\section{Oestrogenic activity of dermally absorbed cosmetic chemicals}

Many component cosmetic chemicals with oestrogenic properties have been measured as present in human breast tissue or human milk $[5,12]$, and direct confirmation of the ability of these chemicals (parabens, phthalates, sunscreens) to be absorbed from topical application in cosmetic cream into the human body has also been published [13-16]. Furthermore, the ability of cosmetic chemicals to be absorbed at sufficient concentrations to exert physiological effects is exemplified by the Mortician's Mystery published in the New England Journal of Medicine in 1988 [17]. This case report demonstrates that long-term topical exposure of hands to embalming creams can result in endocrine disruption to the whole human body, and in particular can affect breast tissue in males [17].

More recent studies report endocrine disruption in women at both young and old age following inappropriate exposure to oestrogenic chemicals in personal care products - including premature breast development and menstruation in a 36-month girl following exposure to hair lotion containing oestrogenic products used by her mother [18], and, at the other extreme of age, abnormal genital bleeding and breast cancer in a 93-year old lady after long-term use of an ethynyloestradiol-containing body care cream [19]. The administration of hormone replacement therapy by skin patches relies on the ability of the hormones to be absorbed from the patch through the skin, but the effects of daily application over the long term of multiple 
cosmetic products containing oestrogenic chemicals warrants equal consideration [5].

Increasing numbers of the component chemicals in cosmetics are now known to possess oestrogenic activity (Table 1) [5-7]. Although many of these compounds, including the parabens, have been termed weak oestrogens because of their low binding affinity to the oestrogen receptor, their efficacy is not low, and they can give the same magnitude of response on growth of human breast cancer cells in vitro as $17 \beta$-oestradiol when sufficient concentration is present [5-7]. Although single chemicals considered in isolation may or may not reach levels in the human breast that are equivalent to those needed for measurable effects in vitro $[5-7,12]$, the environmental reality is that the breast is exposed not to one but to multiple oestrogenic chemicals. The something from nothing effect has demonstrated that mixtures of environmental oestrogens at their no-observedeffect concentrations can give measurable oestrogenic responses in vitro [20], and we have found the same when mixing five different parabens (Figure 1). Furthermore, mixtures of the five parabens can also increase an oestrogenic response at low levels of oestradiol (Figure 1), as might be found at times of low oestrogen concentrations in the menstrual cycle [21], before puberty or after menopause. The breast is known to be susceptible to breast cancer development prior to puberty [22] and in reality most symptoms occur after the menopause [23].

\section{Genotoxic properties of the chemical components}

Clinical studies in 2004 reported increased levels of genomic instability in outer regions of the breast in histologically normal tissue [24], which was suggested to result from exposure to genotoxic chemicals in that region [25]. Instability of the genome is an important contributor to genetic changes that drive carcinogenic processes, and in accordance with the cancer field theory could provide a milieu where genetically altered cells would be more susceptible to the development of cancer $[5,24,25]$.

The active antiperspirant agents are aluminium salts - and aluminium has a known genotoxic profile [26,27], and aluminium chlorhydrate has been shown active in the Comet assay [28]. Use of these salts in cosmetics relies on the inability of the antiperspirant complexes to be absorbed [8]. Dermal absorption of aluminium from topically applied antiperspirant aluminium chlorhydrate, however, has been demonstrated through intact human skin of the underarm [29], and aluminium was measured in human breast tissue at greater levels in outer quadrants than in inner quadrants [30]. Clinical consequences arising from absorbed antiperspirant salts were described in a case study in 2004 reporting adverse bone pain and fatigue associated with toxic blood levels of aluminium, both of which disappeared after discontinuing antiperspirant use [31].
Figure 1

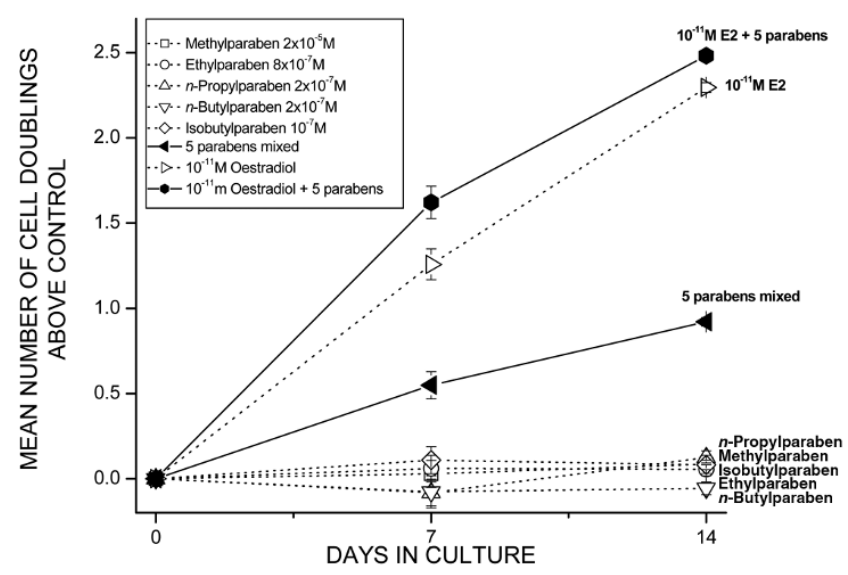

Effect of parabens and oestradiol on growth of MCF7 human breast cancer cells. Effect of five parabens on growth of MCF7 human breast cancer cells individually at no-observed-effect concentration (NOEC) values, of all five parabens mixed together at NOEC values, of $10^{-11} \mathrm{M}$ oestradiol (E2), or of $10^{-11} \mathrm{M}$ E2 together with all five parabens at their NOEC values. Cells were grown and cell growth is presented as published previously [35-37] (AK Charles, PD Darbre, University of Reading, unpublished data).

\section{Could there be a link to inherited susceptibility to breast cancer?}

Development of breast cancer through the inheritance of genetic susceptibility is associated with loss of function of tumour suppressor genes including the BRCA1 and BRCA2 genes, which results in impaired DNA repair processes [32]. The increasing penetrance of these genes in Iceland, however, has suggested that underlying mechanisms of susceptibility can also be influenced by environmental factors as well as genetic factors [33]. Although it is possible that cancers result in these susceptible people from an inability to repair random replication errors, it is also possible that these people are more susceptible to damage from genotoxic pollutant chemicals, including those absorbed from cosmetic products applied around the breast area, than the remainder of the population who have intact DNA repair systems $[2,3,5]$.

\section{Antiperspirant use and breast cysts}

Although cancer assumes the highest profile, it represents only about $5 \%$ of clinical abnormalities of the human breast, with breast cysts and fibroadenomas being the most common benign breast abnormalities [1]. The reason for such a high incidence of benign breast conditions is unknown, but it is notable that the most common site of occurrence of these benign conditions is also the upper outer quadrant of the breast $[1-3,5]$.

On the basis that antiperspirant formulations are designed to block underarm sweat ducts [8] and breast cysts arise from blocked breast ducts in the adjacent region of the body [1], it 
is plausible that breast cysts might also arise from antiperspirant use if sufficient chemicals are absorbed over long periods of usage $[3,5]$. The recent study reporting raised aluminium levels in human breast cyst fluids, most notably from type 1 cysts, compared with serum or milk [34] provides evidence warranting further research into a link between aluminium-based antiperspirant use and breast cyst development.

\section{Conclusions}

Although cosmetic products were used even as long ago as $3500 \mathrm{BC}$ in Ancient Egypt, the mass marketing of recent decades has resulted in unprecedented quantities being now used on the human body and in unprecedented exposure of people across the whole global population. The proposed link between breast cancer and the application of cosmetic chemicals with oestrogenic and/or genotoxic properties provides an evidence-based hypothesis capable of further testing. Although individual chemicals will have been tested by current safety guidelines, the effects of long-term usage of mixtures of these chemicals over an entire lifetime by people of all ages across the whole world warrants retrospective investigation. If use of underarm cosmetics is a factor in the development of breast cancer, then options for prevention could at last become a reality through individual decisions to cease usage or through alterations to product formulations.

\section{Competing interests}

The author declares that they have no competing interests.

\section{Acknowledgement}

This article has been published as part of Breast Cancer Research Volume 11 Suppl 3 2009: Controversies in Breast Cancer 2009. The full contents of the supplement are available online at http://breastcancer-research.com/supplements/11/S3.

\section{References}

1. Haagensen CD: Diseases of the Breast. 2nd edition. Philadelphia: WB Saunders; 1971.

2. Darbre PD: Underarm cosmetics are a cause of breast cancer. Eur J Cancer Prev 2001, 10:389-393.

3. Darbre PD: Underarm cosmetics and breast cancer. J App/ Toxicol 2003, 23:89-95.

4. Darbre PD: Recorded quadrant incidence of female breast cancer in Great Britain suggests a disproportionate increase in the upper outer quadrant of the breast. Anticancer Res 2005, 25:2543-2550.

5. Darbre PD: Environmental oestrogens, cosmetics and breast cancer. Best Pract Res Clin Endocrinol Metab 2006, 20:121143.

6. Harvey PW, Darbre P: Endocrine disrupters and human health: could oestrogenic chemicals in bodycare cosmetics adversely affect breast cancer incidence in women? A review of evidence and call for further research. J Appl Toxicol 2004, 24: 167-176.

7. Darbre PA, Harvey PW: Paraben esters: review of recent studies of endocrine toxicity, absorption, esterase and human exposure, and discussion of potential human health risks. $J$ Appl Toxicol 2008, 28:561-578.

8. Laden K, Felger CB: Antiperspirants and Deodorants. New York: Marcel Dekker; 1988. [Cosmetic Science and Technology Series, vol. 7, edited by Jungermann E]

9. McGrath KG: An earlier age of breast cancer diagnosis related to more frequent use of antiperspirants/deodorants and underarm shaving. Eur J Cancer Prev 2003, 12:479-485.
10. Miller WR: Estrogen and Breast Cancer. London: Chapman Hall; 1996.

11. Mirick DK, Davis S, Thomas DB: Antiperspirant use and the risk of breast cancer. J Natl Cancer Inst 2002, 94:1578-1580.

12. Darbre PD, Aljarrah A, Miller WR, Coldham NG, Sauer MJ, Pope GS: Concentrations of parabens in human breast tumours. J Appl Toxicol 2004, 24:5-13.

13. Janjua NR, Mogensen B, Andersson AM, Petersen JH, Henriksen M, Skakkebaek NE, Wulf HC: Systemic absorption of the sunscreens benzophenone-3, octyl-methoxycinnamate, and 3-(4methyl-benzylidene)camphor after whole-body topical application and reproductive hormone levels in humans. $J$ Invest Dermatol 2004, 123:57-61.

14. Janjua NR, Mortensen GK, Andersson AM, Kongshoj B, Skakkebaek NE, Wulf HC: Systemic uptake of diethyl phthalate, dibutyl phthalate, and butyl paraben following whole-body topical application and reproductive and thyroid hormone levels in humans. Environ Sci Technol 2007, 41:5564-5570.

15. Janjua NR, Frederiksen H, Skakkebaek NE, Wulff HC, Andersson AM: Urinary excretion of phthalates and paraben after repeated whole-body topical application in humans. Int J Androl 2008, 31:118-130.

16. Janjua NR, Kongshoj B, Andersson AM, Wulff HC: Sunscreens in human plasma and urine after repeated whole-body topical application. J Eur Acad Dermatol Venereo/ 2008, 22:456-461.

17. Finkelstein JS, McCully WF, MacLaughlin DT, Godine JE, Crowley WF: The Mortician's Mystery: gynecomastia and reversible hypogonadotropic hypogonadism in an embalmer. $N$ Engl $J$ Med 1988, 318:961-965

18. Guarneri MP, Brambilla G, Liozzo A, Colombo I, Chiumello G: Estrogen exposure in a child from hair lotion used by her mother: clinical and hair analysis data. Clin Toxicol 2008, 46: 762-764.

19. Komori S, Ito Y, Nakamura Y, Aoki M, Takashi T, Kinuta T, Tanaka $\mathrm{H}$, Koyama $\mathrm{K}$ : A long-term user of cosmetic cream containing estrogen developed breast cancer and endometrial hyperplasia. Menopause 2008, 15:1191-1192.

20. Rajapakse N, Silva E, Kortenkamp A: Combining xenoestrogens at levels below individual no-observed-effect concentrations dramatically enhances steroid hormone action. Environ Health Perspect 2002, 110:917-921.

21. Wright JV, Schliesman B, Robinson L: Comparative measurements of serum estriol, estradiol, and estrone in non-pregnant, premenopausal women: a preliminary investigation. Alt Med Rev 1999, 4:266-270.

22. Russo J, Russo IH: Biology of disease. Biological and molecular bases of mammary carcinogenesis. Lab Invest 1987, 57: 112-137.

23. Key TJ, Verkasalo PK, Banks E: Epidemiology of breast cancer. Lancet Oncol 2001, 2:133-140.

24. Ellsworth DL, Ellsworth RE, Love B, Deyarmin B, Lubert SM, Mittal MD, Hooke JA, Shriver CD: Outer breast quadrants demonstrate increased levels of genomic instability. Ann Surg Oncol 2004, 11:861-868.

25. Ellsworth DL, Ellsworth RE, Liebman MN, Hooke JA, Shriver CD: Genomic instability in histologically normal breast tissues: implications for carcinogenesis. Lancet Oncol 2004, 5:753758.

26. Exley C: Aluminium and Alzheimer's Disease: The Science that Describes the Link. London: Elsevier; 2001.

27. Darbre PD: Aluminium, antiperspirants and breast cancer. $J$ Inorg Biochem 2005, 99:1912-1919.

28. Yiu G: Antiperspirant induced DNA damage in canine cells by Comet assay. Toxicol Mech Methods 2005, 15:25-28.

29. Flarend R, Bin T, Elmore D, Hem SL: A preliminary study of the dermal absorption of aluminium from antiperspirants using aluminium-26. Food Chem Toxicol 2001, 39:163-168.

30. Exley C, Charles LM, Barr L, Martin C, Polwart A, Darbre PD: Aluminium in human breast tissue. $J$ Inorg Biochem 2007, 101: 1344-1346.

31. Guillard O, Fauconneau B, Olichon D, Dedieu G, Delonche R: Hyperaluminemia in a woman using an aluminium-containing antiperspirant for 4 years. Am J Med 2004, 117:956-959.

32. Yoshida K, Miki Y: Role of BRCA1 and BRCA2 as regulators of DNA repair, transcription, and cell cycle in response to DNA damage. Cancer Sci 2004, 95:866-871.

33. Tryggvadottir L, Sigvaldason H, Olafsdottir H, Jonasson JG, 
Jonsson T, Tulinius $\mathrm{H}$, Eyfjord JE: Population-based study of changing breast cancer risk in Icelandic BRCA2 mutation carriers, 1920-2000. J Nat/ Cancer Inst 2006, 98:116-122.

34. Mannello F, Tonti GA, Darbre PD: Concentration of aluminium in breast cyst fluids collected from women affected by gross cystic breast disease. J App/ Toxicol 2009, 29:1-6.

35. Byford JR, Shaw LE, Drew MG, Pope GS, Sauer MJ, Darbre PD: Oestrogenic activity of parabens in MCF7 human breast cancer cells. J Steroid Biochem Mol Biol 2002, 80:49-60.

36. Darbre PD, Byford JR, Shaw LE, Horton RA, Pope GS, Sauer MJ: Oestrogenic activity of isobutylparaben in vitro and in vivo. $J$ Appl Toxicol 2002, 22:219-226.

37. Darbre PD, Byford JR, Shaw LE, Hall S, Coldham NG, Pope GS, Sauer MJ: Oestrogenic activity of benzylparaben. J Appl Toxicol 2003, 23:43-51. 